\title{
Monetary Policy and the Price Rule: The Newest Odd Couple
}

\author{
R. W. HAFER
}

M

ONETARY policy is not formulated in a vacuum; it always follows some guideline. Over the years, monetary policy guidelines have taken many forms: controlling the quantity of money as a set ratio to the stock of gold, pegging a specific interest rate and, currently, targeting directly on the growth of one or more monetary aggregates.

During the past few years, detractors of the monetary targeting approach have called for alternative control procedures. Some have argued for the use of broader measures of money and credit. ${ }^{1}$ Others have urged that "real" interest rate targets be used in formulating monetary policy, ${ }^{2}$ Still others have called for the re-introduction of a gold-standard type of policy. ${ }^{3}$

Another recommendation gaining popularity is for monetary policymakers to vary the stock of money to offset short-run changes in some measure of prices. Advocates of stich a short-run "price rule" maintain that the procedure ensures a better control over inflation and concomitantly decreases the public's uncertainty about the future direction of monetary policy. ${ }^{4}$

\footnotetext{
'See the recent arguments of Benjanin Friedman, "Time to Reexamine the Monetary Targets Franework, Netu England Economic Review (March/April 1952), pp. 15-23, and Benjamin Friedman, "A Two-Target Strategy for Monefary Policy," Wall Streef Journal Jinuary $27,1983$.

${ }^{2}$ For a discussion of this issue, see $\mathrm{G}$. I. Santoni and Courteray $\mathrm{C}$. Stone, "The Fed and the Real Rate of Interest," this Reviet (December 1982), pp. \&-18.

${ }^{3}$ For a look at the aryuments, see Report to the Congress of the Commission on the Role of Gold in the Domestic and Intermational Monetary Sustems (U.S. Government Printing Offee, March 1982). For a useful retrospect of the commission and its report, see Ama I. Schwartz, "Reflections on the Gold Commission Report," Journalof Money, Credit and Banking (November 1982 , pt. 1), pp. $538-51$.

tRecent arguments favoring this form of price rule are fomd in Robert Cenetski, "The Benefits of a Price Rule" Wall Street Journal, December 10, 1982; "Unraveling?" Wall Street Jourmal January 21, 1983, Robert Mundell, "The Debt Crisis: Causes and Solutions," Wall Street Journal, January 31, 1983; and Alan Reynolds, "The Trouble with Monetarism," Policy Retiete (Summer 1982), pp. $19-12$.
}

Although the alleged benefits of this proposal have been discussed in the popular press, its disadvantages have not been examined in any great detail. The purpose of this article is to examine the current feasibility of a short-run price rule for monetary policy.

\section{WHAT}

In essence, a price rule requires that the monetary authority attempt to maintain a chosen price index at a particular level by varying the stock of money. In other words, the sole function of policy is to prevent the price index from deviating substantially from a predetermined level. This is equivalent to keeping the relevant inflation rate at zero.

The theoretical attraction of this approach is that, if successful, it would maintain the purchasing power of the dollar. Consider, for example, the decade of the 1970 s in which prices rose considerably. If we compare the purchasing power of today's dollar with the 1972 dollar, today's dollar buys less than half of the goods and services that one dollar bought at 1972 prices. For instance, the GNP deflator - a broad measure of

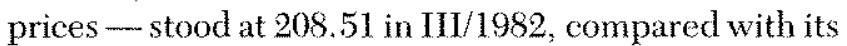
level of 100 in 1972 (the base year). This means that a dollar today buys only 48 cents worth $(100 \div 208.51)$ of goods and services compared to what it bought in 1972 .

The desirability of knowing the dollar's future pur. chasing power is obvious. This knowledge would simplify activities such as planning an investment strategy or contracting. Stable prices also would result in lower market rates of interest; the cost of borrowing against future income is reduced when there is less uncertainty about future prices.

There are two approaches to maintaining the level of prices. The major difference between the two is the time frame used to implement policy. One approach emphasizes the importance of controlling and reducing the trend or long-run money growth in order to reduce the trend or long-run rate of inflation to zero. This 


\section{Table 1}

\section{Selected Price Indexes and Their Major Components'}

\begin{tabular}{|c|c|c|c|}
\hline GNP & $\mathrm{CPI}$ & PPI & $\mathrm{AICP}$ \\
\hline 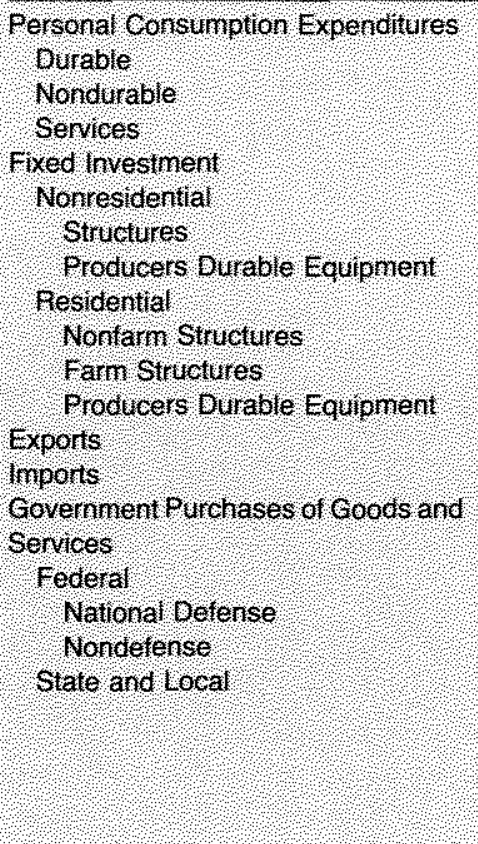 & 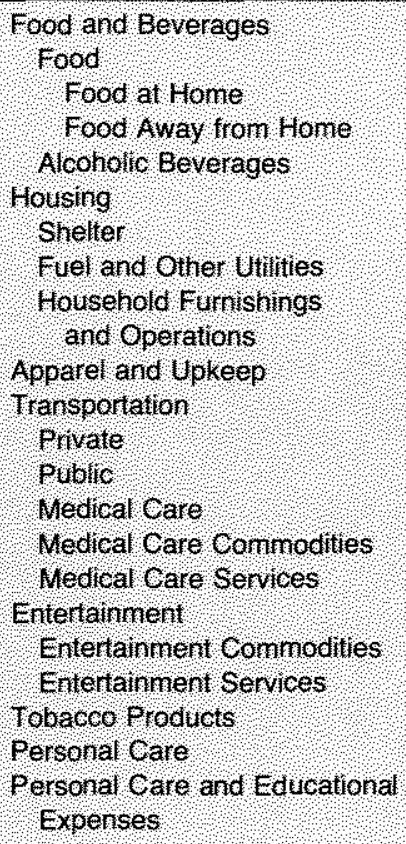 & 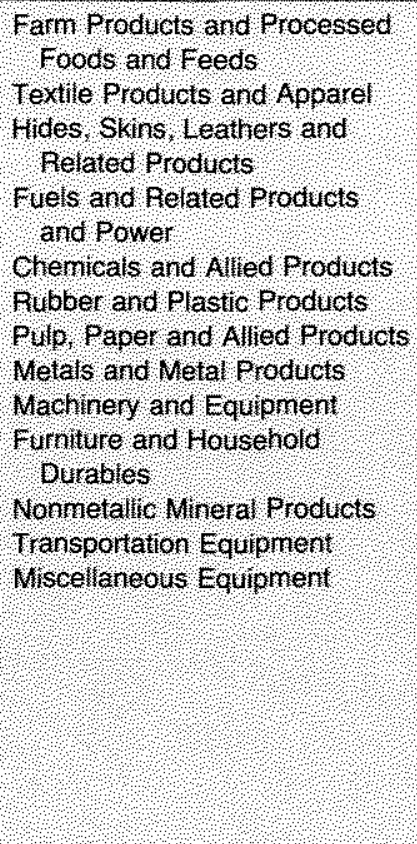 & $\begin{array}{l}\text { Copper Scrap } \\
\text { cead Scrap } \\
\text { steel Scrap } \\
\text { Tin } \\
\text { Zine } \\
\text { Burlap } \\
\text { Cotton } \\
\text { Print cloth } \\
\text { Wool Taps } \\
\text { Cow Hides } \\
\text { Rosin, Wridow } \\
\text { Glass } \\
\text { Rubber } \\
\text { Tellow }\end{array}$ \\
\hline
\end{tabular}

TGNP represents the GNP deflator, CPl is he Consuner Price index, PPI is the Producer Price lidex and RlCP is he Raw Industrial Commodity Price lndex

approach - essentially that advocated by monetarists - is presumed to underlie current monetary policy actions.

The other approach emphasizes varying the stock of money to offset short-term price changes (e.g., less than a year). The problems inherent in this latter approach are the focus of this article.

\section{THE PROBLEM OF CIOOSNG AN MEE}

Before one can establish a price rule for monetary policy, one must determine which price index to use as a guide. This selection can be quite difficult because it involves answering the following questions: How broad should the index be? Should it include only final goods? Intermediate goods? Raw materials? How closely should changes in the index parallel changes in the money stock? Over what time period should the comparisons be made?

\section{There Are a Wide Vurety of nderes...}

Numerous price indexes currently are calculated for the U.S. economy. They range from the broadly inclusive and widely used GNP deflator to the highly specialized Raw Industrial Commodity Price (RuCP) index. Somewhere between these two in coverage are the Consumer Price Index (CPI) and the Producer Price Index (PPI). Table 1 provides a breakdown of each index into its major components.

As seen in table 1, the coverage of the indexes does not always overlap. Some indexes, like the CPI, represent prices for final goods - that is, goods that have completed the production process - and include nonm commodity items like services, rent, interest charges and entertainment. The RICP index, however, measures prices during or before the production process. Consequently, this index represents the prices charged to producers of goods and services which, when sold to the final consamer, will appear in the CPI.

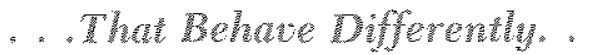

Table 2, which presents the simple correlation among growth rates for each index over a variety of hime periods, shows just how closely the different 


\section{Table 2}

\section{Simple Correlations Between Growth Rates of Price Indexes}

\begin{tabular}{|c|c|c|c|c|c|}
\hline \multirow{2}{*}{ najores } & \multicolumn{5}{|c|}{ Perrod } \\
\hline & $11960-11 / 1982$ & $1 / 960-1 / 1964$ & 11965 V 1960 & $11970-1 / 1974$ & $11975-11 / 1982$ \\
\hline GNPCPI & $090^{2}$ & 018 & 0,81 & $0.90^{\prime}$ & $076^{\circ}$ \\
\hline GNPPPI & $0.65^{2}$ & 002 & 0,28 & $0,62^{2}$ & $0.46^{2}$ \\
\hline GNPRICP & 007 & 018 & 044 & 0011 & 4011 \\
\hline CPIPPI & $0.73^{2}$ & 0.40 & 039 & 0718 & 0.67 \\
\hline OPH RICP & 016 & 0,16 & 045 & 009 & 012 \\
\hline PPIPLP & $0.46^{2}$ & 1004 & 0.68 & 043 & $0,49^{2}$ \\
\hline
\end{tabular}

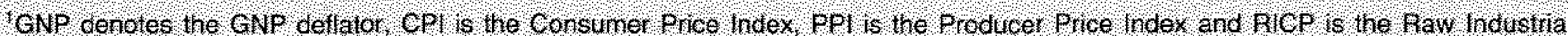
Commodities Price hdex All grow h rates are compounded annual rates of change.

Statistically different tron zero ot the 95 percent level of signilcance

indexes move together. ${ }^{5}$ Looking first at the left-hand column, which shows the correlation coefficients for the $\mathrm{I} / 1960-\mathrm{III} / 1982$ period, we see that the size of the correlations declines as the disparate nature of the indexes increases. For example, over the full period, the simple correlation between the GNP deflator and the CPI is 0.90 . This drops to 0.65 for the GNP deflator-PPI comparison and to 0.07 - a value not statistically different from zero - when we compare the deflator's movements to those of the RICP index. Not unexpectedy, the correlations reveal a closer relationship between movements in the PPI and the RICP. $(0.46)$, because the coverage of these two measures is more similar. Thus, as a rule, the more closely the two indexes are defined, the greater the correlation between them.

The most interesting aspect of table 2 is the variety of correlations over the shorter time spans. For instance, the correlation between the CNP deflator and the CPI ranges from -0.18 to 0.90 . Similarly, the correlation between the GNP deflator and the RICP index varies from a high of 0.44 to a low of -0.11 . The correlations over shorter periods are quite volatile and, in many instances, not statistically different from zero. "This indicates that, except perhaps for the GNP-CPI link since 1965, no easily discernible relationship what soever exists between the indexes shown. This result arises, in part, because the indexes differ in their coverage of goods and services.

\footnotetext{
The correlation coefficient captures the degree of closeness in the movements of two series. It ranges from -1.0 to 1.0 , indicatingt. respectively, perfectly opposing and perfectly coordinated movements. Thus, if the two series are unrelated, the correlation coef fient will be dose to zero. For a description of the statistic, see Panl G. Hoel, Introduction to Mathematical Statistics (Jom G Wley \& Sons, Inc., 1962), pp. 16368.
}

\section{" Because Different" "Weighes" Are Used : =}

We have seen that the coverage of the indexes is different. At the same time, their construction necessitates that the various components be assigned some "weight." This weight helps to determine the relative importance of the item in the "basket" of goods and services represented by the index. This differential treatment of components can produce a dilemma for policymakers if movements in the overall index are dominated, temporarily at least, by fuctuations in one or two component prices. For example, if one component increases sharply and it has a relatively large weight, the index will increase even though other prices have not changed. This effect - called a relative price shock - will cause the index to increase rapidly, giving the appearance of a general increase in prices. ${ }^{6}$

To illustrate this, chart 1 plots the rate of inflation measured two ways: one by the CPI, the other by the CPI minus energy prices. Notice how different the two inflation rate series are during periods when energy prices increased more rapidly than other prices in the CPI. During the oil price shocks of 1974 and 1979 , the CPI inflation rate is noticeably higher when energy prices are included than when they are excluded.

\footnotetext{
"Analyses of the impset of "relative price shocks" on measured price indexes are provided in Alan $S$. Blinder, "The Consumer Price Index and the Measurement of Recent Inflation,"Brookings Papers on Economic Activity (2: 1980), pp. 539-65; Stanley Fisch. er, "Relative Shocks, Relative Price Variability, and Inflation," Brookings Papers on Economic Activity (2: 1981), pp. 381-431; and Lawrence S. Davidson, "Inflation Misinformation and Monetary Policy," this Reciew (Jne/July 1982), pp. 15-26.
} 


\section{Chart 1 \\ Inflation Rates of the CPI and the CPI Less Energy Prices $L$}

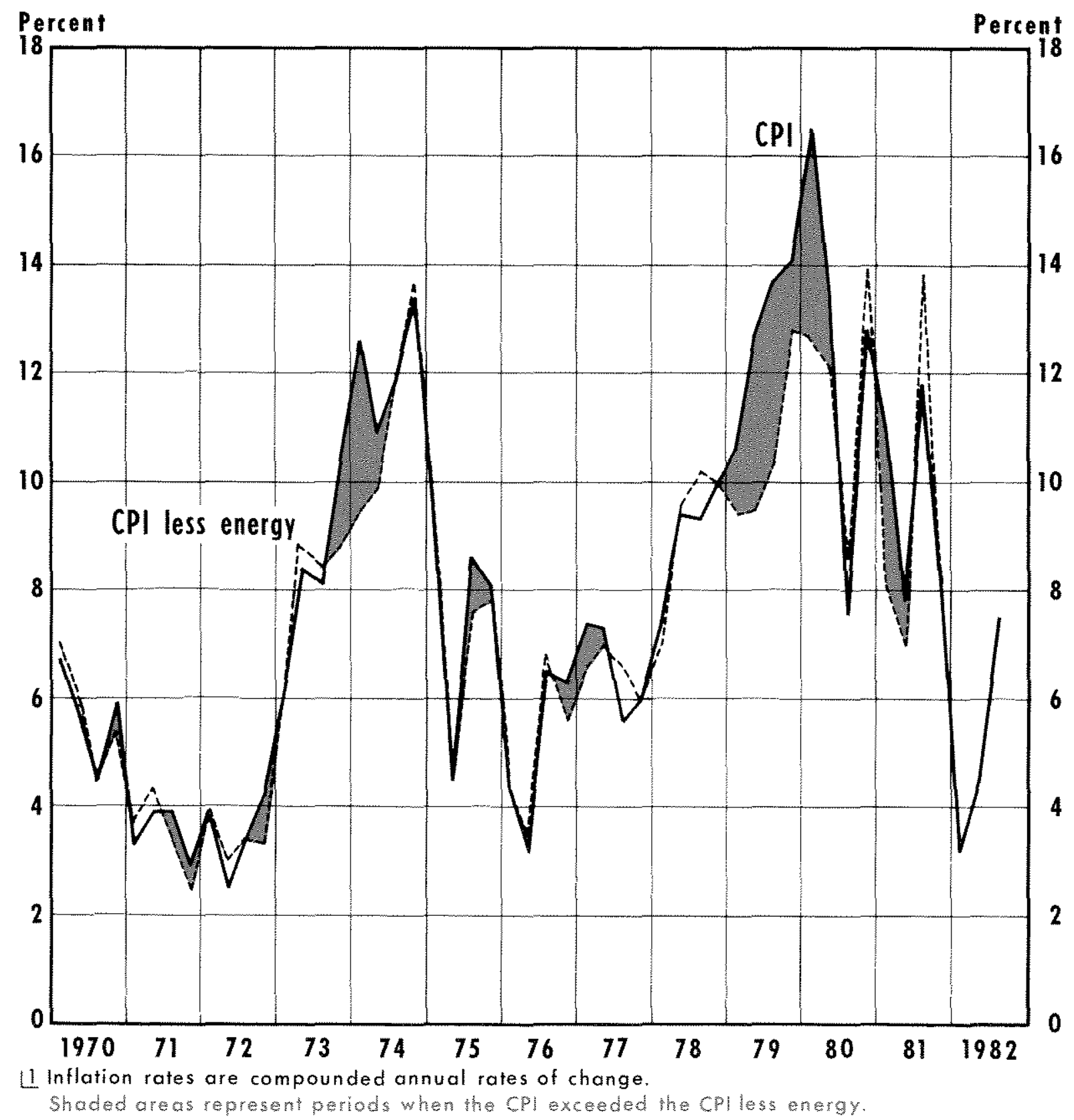

To further demonstrate the impact that changes in the price of one important commodity group can have on an index, chart 2 plots the inflation rates of the PPI and the PPI minus fuels and related products and power. Again, there is a noticeable difference in the two series during periods of rapidly rising energy prices.

To illustrate the problem that this data might pose for policy, suppose the monetary authority used the PPI on which to base its decision about future money 


\section{(ande \\ Inflation Rates of the PPI and the PPI Less Fuels and Related Products and Power 11}

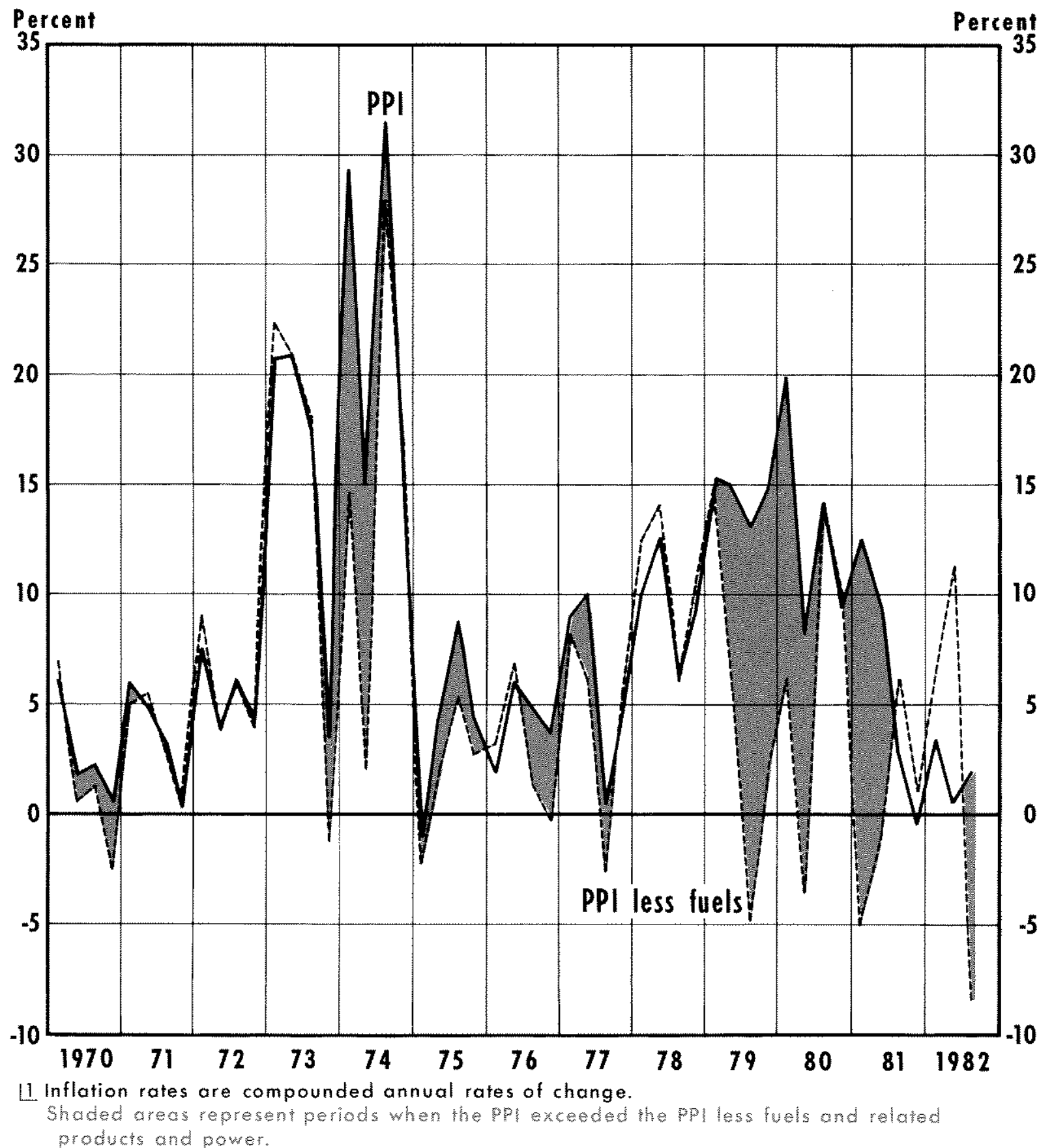

growth. In $\mathrm{I} / 1980$, it would have faced an inflation rate during the preceding year of over 16 percent. Under a short-term price rule, this clearly would call for a drastic reduetion in money growth. If the authority instead used the PPI "minus energy" as its yardstick of price change, the average rate of increase during the preceding year would have been only 2 percent. This would call for a totally different monetary policy response. 
Table 3

Simple Correlations Between Inflation Measures and Money Growth ${ }^{1}$

\begin{tabular}{|c|c|c|c|c|c|}
\hline \multirow{2}{*}{ rice } & \multicolumn{5}{|c|}{ peroo } \\
\hline & $1 / 960,11 / 1982$ & $1 / 960, \mathrm{~N} / 1964$ & $1 / 1965 / 1 / 969$ & $1 / 97011 / 974$ & $1 / 1975-11 / 1982$ \\
\hline \multicolumn{6}{|c|}{ LONG-BUN } \\
\hline GNP & $083^{\circ}$ & 007 & $076^{3}$ & $049^{9}$ & 0,59 \\
\hline opl & $0.82^{3}$ & 030 & $0.89^{\circ}$ & 062 & $068^{3}$ \\
\hline PPI & $0.64^{\circ}$ & 002 & 035 & $065^{\circ}$ & $063^{3}$ \\
\hline nes & 026 & 077 & 0.43 & $062^{3}$ & 0,13 \\
\hline \multicolumn{6}{|c|}{ SHOFT RUN } \\
\hline GNP & $040^{\circ}$ & 001 & 0,33 & 0038 & 0,15 \\
\hline oP & 0.45 & 037 & 0.39 & 0.38 & 032 \\
\hline PP & 0028 & 0.01 & 046 & 4005 & 0.15 \\
\hline nICP & $028^{\circ}$ & 9,35 & 047 & 0,28 & 009 \\
\hline
\end{tabular}

Long-ruh noney grovth is neasured as a 12 -quarter noving average of M growth short run money growth is the money growth rate lagged one quarter elative to proes.

SSee notes accompanying table 2 lor detintion of price indexes.

Statistically different trom tero al the 95 percent level of signifcance.

Thus, relative price shocks - the source of which often lies beyond the power of monetary policymakers to influence - have direct implications for policy actions. Determining the source, magnitude and duration of such aberrations - clearly no small task would be necessary under a short-run price rule.

\section{...Which Produces a I roblem for Policymakers}

The point of the previous exercise is to illustrate the difficulty in selecting a price index to guide monetary policy actions. How should policymakers react to relative price shocks that change the measured rate of inflation? Should money growth be reduced in the face of an increase in the price index when, in fact, the increase can be traced directly to relative movements in one component of the index?

Evidence presented elsewhere indicates that relative price shocks are of short duration in their effect on the overall inflation rate. ${ }^{7}$ Thus, if monetary policy attempts to quell observed increases in a price index caused by non-monetary relative price shocks, it will serve only to exacerbate the problem of price stability once the effects of the relative price shock abate.

In summary, the adoption of a price rule for mone-

Thide. tary policy must first address the thorny issue of selecting a specific price index. This selection is complicated for several reasons. First, there are a variety of indexes from which to choose; each has a different coverage and a different pattern of behavior. Second, they are all subject to temporary movements that represent the effect of some relative price change; thus, policymakers must distinguish those movements in the index to which they should respond from those movements they should ignore.

\section{MONEY GROWTU AND INFEATON}

A necessary condition for a short-run price rule to function properly is that the chosen price index respond quickly and reliably to changes in the money stock. This is, after all, the very heart of the suggested procedure. Because a price rule assumes that the underlying cause of inflation is a change in the growth of the money stock, it is important to examine just how quickly movements in the price indexes respond to money growth.

Table 3 presents evidence on the relationship between the growth in money (M1) and four measures of inflation. 8 simple correlation between inflation and

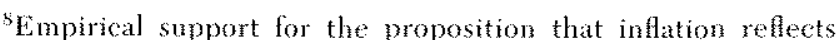
changes in the growth of money is provided to Denis $\mathrm{S}$. Kamosky, "The Link Between Money and Prices - 1971-76." this Review
} 
M1 growth is used to capture the association. The "long-term" rate of Ml growth used to examine this association is measured as a 12 -quarter moving average. These correlations appear in the upper half of table 3. Correlations between the various inflation measures and "short-term" M1 growth, represented by the one-cuarter lagged growth rate, are used to assess the short-run impact of MI growth on inflation. These are shown in the lower half of table 3 . The correlations are calculated for the same time periods used in table $2 .^{9}$

A comparison of the results reveals that inflation generally exhibits a closer relationship to longer-term movements in $M I$ than to its short-term changes. The full-period results (I/1960-UIJ/1982) indicate that the correlation between inflation and $\mathrm{M} 1$ growth is about twice as great using long-term relative to short-term money growth. This suggests that prices are more responsive to the changes in Ml that have occurred during the preceding three-year period than to the changes in the previous quarter. Thus, altering the growth of $\mathrm{Ml}$ in response to current changes in a price index - changes that are actually the result of policy actions during the past three years - aggravates the volatility of prices over the long run.

For shorter time periods, the moneymprice link is quite variable. Except for the RICP index and the PPI, the correlation between long-term money growth and inflation drops noticeably during the $1970-74$ period. This is due primarily to the non-monetary factors - for example, the imposition and removal of wage and price controls and the OPEC oil price increases - that affected some prices relatively more than others during this era.

For a short-run price rule to work effectively, prices must respond quickly and reliably to changes in the money stock. The evidence in table 3 demonstrates that this is not the case. The correlation between price changes and short-run money growth is extremely variable across different time periods: in some periods,

(June 1976), pp. 17-23; Keith M. Carlson, "The Lag from Money to Prices," this Review (October 1980), pp. 3-10; and John A. Tatom, "Energy Prices and Short-Ren Economic Pefformance," this Review (January 1981), pp. 3-17. It is this type of evidence on which the argument for reducing the long-term rate of inflation by reducing the trend rate of money growth is based.

An alternative view is represented in George L. Perry, "Inflation in "Theory and Practice," Brookings Papers's on Economic Activity (1: 1980 ), pp. $207-41$.

The analysis also was done using a 20 -quarter moving average of Ml growth as the long-run measure. This change did not alter the conclusions reached in the text. there is a positive relationship, while in others it is negative. Indeed, this is true regardless of the index used. More important, only 2 out of 16 subperiod correlations reported in table 3 are statistically different from zero at the 95 percent level of confidence for the short-run correlations. In contrast, 10 out of 16 subperiod correlations are significantly different from zero for the long-run correlations.

Thus, the evidence indicates that the various price indexes do not respond to changes in short-run MI growth in a sufficiently reliable manner to make a price rule practical for short-term policy horizons. The correlations do reveal, however, the existence of a reliable long-run connection between price changes and money growth.

\section{A PRTCE RULE MONETARY POLICA AND VARLABLE MONEY GROWTH}

Variable money growth can affect real economic activity in the short run. As noted previously, in the long run, changes in money growth are reflected in price changes. During the short run, however, changes in money growth first affect spending and production decisions. If money growth declines far enough and long enough from its established trend, it then leads to a downturn in real economic activity.

To illustrate this point, chart 3 plots the trend rate of Ml growth, measured as a 20 -quarter moving average, and its short-run growth, depicted by a 2-quarter moving average. Recessions are designated by shaded areas.

Chart 3 depicts the common relationship during the past two decades between sharp reductions in shortrun $M I$ growth relative to its trend and real economic activity. "Prior to each recession, substantial reductions in short-run $\mathrm{Ml}$ growth relative to trend occurred. For example, short-run M1 growth fell from

\footnotetext{
${ }^{10}$ Clark Warbarton was a pioneer in this type of analysis. See his "Bank Reserves and Business Fluctutions," Jotrnal of the American Statistical Association (December 1948), pp. 547-58, reprinted in Depression, Inflation, and Monetary Policy: Selected Papers 1945-1953 (The Johns Hopkins Press, 1966). Similar andyses are presented by Wilton Friedman and Amna I. Schwartz, "Money and Business Cycles," Reviete of Economics and Statistics (February 1963), pp. 32-78; William Poole, "The Relationship of Monetary Decelerations to Business Cycle Peaks: Another Look at the Evidence." Jottmal of Finance (J me 1975), pp. 697712; and Dallas S. Batten and R. W. Hafer, "Short-Fue Money Growth Fluctuations and Real Economic Activity: Some Implications for Monetary Targeting," this Review (May 1982), pp. 15-20. An analysis using a 12 -quarter moving average of money growth did not alter the findings reported in the text.
} 
Chart 3

Rates of Change of Money Stock (MI)

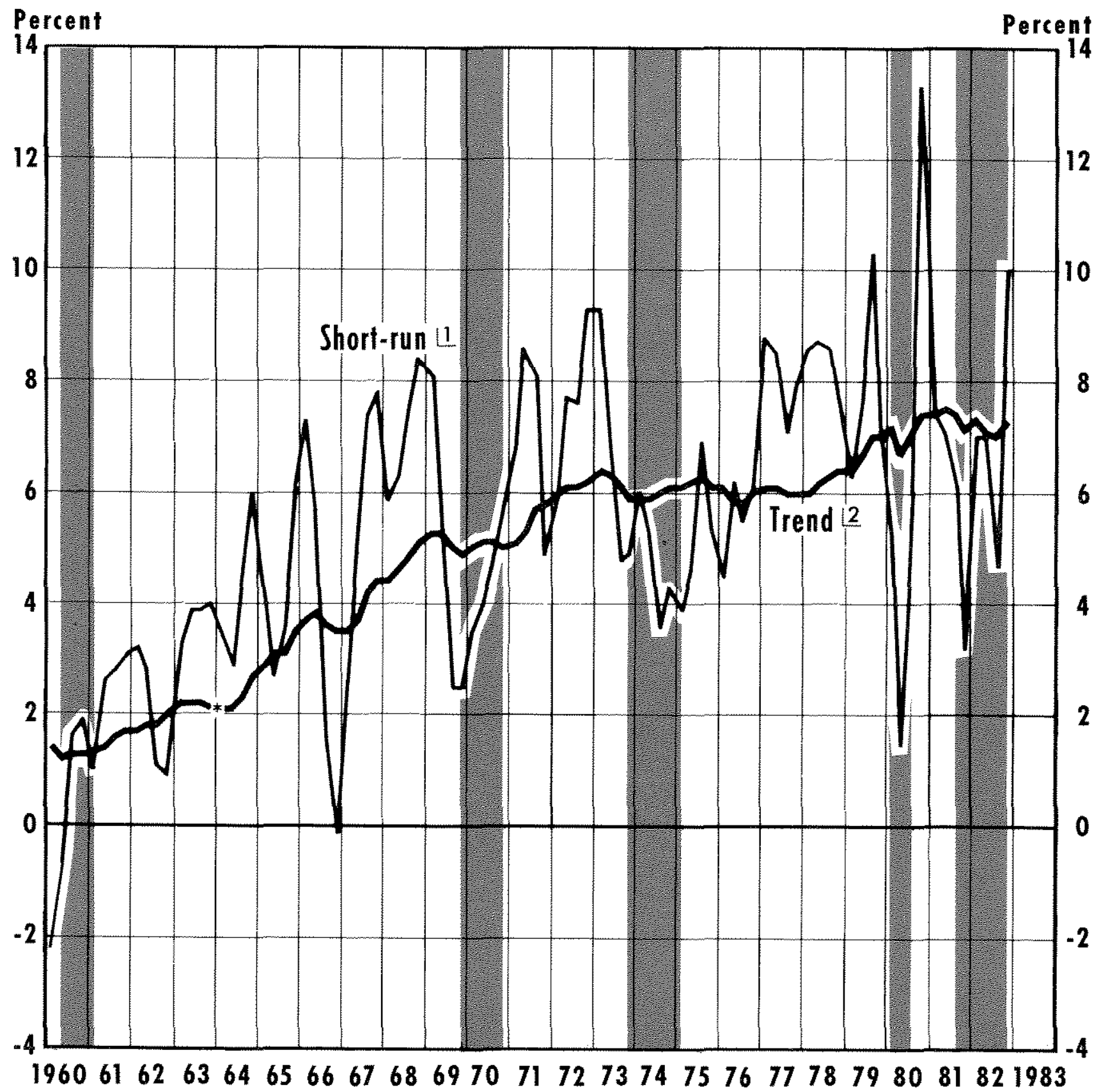

1 Two-quarter rate of change.

L2 Twenty-quarter rate of change; data prior to 1 st quarter 1964 are $M 1$ on the old basis.

shoded areas represent periods of business recessions. 
about 2 percentage points above its trend to about 5 percentage points below trend within several quarters prior to the II/1980-11L/1980 recession. A similar pattern of rapid deceleration in $\mathrm{Ml}$ growth relative to trend precedes the most recent recessionary episode during 1981 and $1982 .^{11}$

The implementation of monetary policy using a short-run price rule necessitates varying the growth of the money stock in response to changes in some price index. Consequently, it is likely that the growth of the money stock would be more variable under a price rule than it would be under a monetary targeting rule. The prospect of increased variability of money growth is an additional factor that argues against the adoption of a short-run price rule.

\section{CONCIUSON}

Advocates of a short-run price rule approach to monetary policy argue that it is superior to current policy actions. While the arguments supporting a

\footnotetext{
${ }^{11}$ Indeed, the dramatic slowing in short-run $\mathrm{Ml}$ growth relative to its trend and the increase in its volatility (i.e., short-run MI growth that is far above and below trend) during the past two years have been associated with substantial reductions in real economic activity. From IV/1979 to N/1982, real output decreased at a 0.4 percent rate. The standard deviation of money growth during this period was 5.91 percent. In comparison, the standard deviation of money growth from IV/1976 to $111 / 1979$ was 1.45 percent.
}

short-run price rule might seem appealing at first glance, the facts suggest that this approach is unlikely to achieve its promised goal of price stability in either the short- or the long-run.

There are a variety of problems that beset the shortrun price rule for monetary policy: Which price index should be chosen? What should be done about relative price change effects on the observed index? What will the policymaker's response be if variations in the money stock to achieve short-run price stability threaten to impede economic activity?

The evidence presented in this article indicates that these problems are critical in discussing the adoption of a price rule for monetary policy. Perbaps the most damaging of all the evidence is the finding that shortrun money growth has widely different effects on the various price indexes investigated in this article. In fact, there does not appear to be a simple stable relationship between short-run movements in the money stock and the different price indexes that is necessary for the success of a price-rule monetary policy.

Finally, a price rule calls for varying the short-run growth of money in an attempt to achieve and maintain a zero rate of inflation. The evidence suggests that such variation in monetary growth could well lead to lower growth in real economic activity and conld even produce frequent recessions if the variations in $\mathrm{M} I$ growth were sufficiently drastic and prolonged.

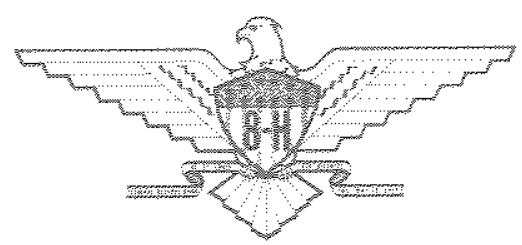

